DOI: 10.46340/eppd.2021.8.5.17

Volodymyr Belenok

ORCID ID: https://orcid.org/0000-0001-8214-0522

National Academy of Internal Affairs, Kyiv, Ukraine

\title{
TYPOLOGY OF PERPETRATORS OF THREATS OR VIOLENCE AGAINST LAW ENFORCEMENT OFFICERS
}

\author{
Володимир Беленок \\ Національна академія внутрішніх справ, м. Київ, Україна \\ ТИПОЛОГІЯ ОСІБ, ЯКІ ВЧИНЯЮТЬ ПОГРОЗИ \\ АБО НАСИЛЬСТВО ЩОДО ПРАЦІВНИКІВ \\ ПРАВООХОРОННИХ ОРГАНІВ
}

In criminological characteristics of criminal offenses, the characteristics of the perpetrators are important. At the same time, in the criminological characteristics of persons who commit threats or violence against law enforcement officers, an important place is given to the classification of such violators on various grounds and the development of their typology. The article develops a typology of such persons on the basis of analysis of judicial practice, a survey of law enforcement officers, the study of scientific literature. It includes the classification of criminal offenders of this category according to such criteria as the stability of antisocial orientation of the offender (situational (unstable), forced, malicious (stable), especially dangerous types), his relationship with the victim (previously acquainted with victim or not), motives (useful, prestigious, vindictive), purpose (evading an administrative or criminal offense; retaliation for lawful or illegal actions of a law enforcement officer), type (method) of socially dangerous acts, experience of other criminal offenses (persons, who have not previously committed criminal offenses; suspects, accused of committing criminal offenses; convicted, previously convicted), intoxication at the time of criminal offense, type of offense that precedes threats or violence against a law enforcement officer, as well as the number of subjects of the crime and the form of complicity (individually; as part of a group without prior agreement or with such; as part of an organized criminal organization). These and other classification criteria, as well as the types of offenders in this category identified on their basis, allow a differentiated and comprehensive approach to the formation of tactics and strategies to combat threats or violence against law enforcement, especially police, and form a system of adequate measures to prevent these socially dangerous acts.

Keywords: threat, violence, law enforcement officer, close relatives, identity of criminal, subject of crime.

Постановка проблеми. Серед пріоритетних завдань розбудови України як правової держави європейського зразка є створення ефективної правоохоронної системи, важливою складовою якої $є$ забезпечення високого рівня захисту правоохоронців. Саме ефективність діяльності вітчизняних правоохоронних органів певною мірою залежить від рівня захисту прав і свобод їх працівників, який, з огляду на виконувані ними функції, повинне мати високий ступінь. Насамперед, слід створити належні умови захисту життя та здоров'я правоохоронців, котрі щоденно перебувають в умовах небезпеки посягань з боку осіб, що вчиняють адміністративні чи кримінальні правопорушення. Особливої небезпеки зазначені посягання набувають в умовах 
зростання рівня корупції, організованої злочинності та тероризму, на чому неодноразово наголошували вчені ${ }^{1}$.

Забезпечення ефективної системи кримінально-правової охорони працівників правоохоронних органів від погроз та насильства, а також запобігання цим кримінально протиправним діянням неможлива без вивчення особи злочинця, зокрема, типології осіб, які вчиняють ці злочини.

Аналіз останніх досліджень і публікацій. Окремі кримінально-правові, кримінологічні та криміналістичні особливості осіб, які вчинили погрози або насильство щодо працівників правоохоронних органів, досліджено у працях А. В. Бойка, Л. П. Брич, О. О. Кирбятєва, В. А. Клименка, В. І. Осадчого, М. В. Сийплокі, А. М. Удода, І. Д. Метельського та інших науковців. Разом із тим, чимало питань кримінологічної характеристики осіб, які вчинили погрозу або насильство щодо працівника правоохоронного органу залишаються недостатньо дослідженими.

Мета статті - на підставі наявної емпіричної бази, а також досліджень вчених сформулювати типологію осіб, які вчиняють погрози або насильство щодо працівників правоохоронних органів.

Виклад основного матеріалу.

Важливе місце у кримінологічній характеристиці осіб, які вчиняють погрози або насильство щодо працівників правоохоронних органів відводиться класифікації таких порушників за різними ознаками, тобто розробленню їх типології.

Опитані працівники ДВБ виділили такі категорії осіб, які вчиняють ці злочини:

1) які перебували у стані алкогольного (60\%), рідше наркотичного (33,9\%) сп'яніння, зокрема мали відповідну залежність та не в повній мірі усвідомлювали наслідки своїх дій;

2) раніше судимі (36,9 \%), зокрема за злочини пов'язані з насильством, проти власності, життя та здоров'я особи;

3) які вчинили кримінальне чи адміністративне правопорушення (домашнє насильство, хуліганство, кримінальні правопорушення проти власності, життя та здоров'я особи, пов'язані 3 насильством тощо). У результаті чого таких осіб затримують або складають щодо них протокол про адміністративне правопорушення. У певних випадках вони намагаються уникнути відповідальності;

4) які ведуть аморальний (антисоціальний) спосіб життя (займають соціально шкідливу життєву позицію), переважно офіційно не працевлаштовані (прибутки отримують разові від виконання певних замовлень);

5) з низьким соціальним статусом та рівнем життя;

6) потерпілі від неправомірних, зокрема, кримінально-протиправних дій поліцейських;

7) потерпілі або їх родичі, які не задоволенні результатами досудового розслідування кримінального провадження;

8) підозрювані або їхні представники, які не задоволенні кваліфікацією злочинів, способом отримання доказів, вироком суду тощо;

9) які перебувають у збудженому чи нестійкому емоційному стані, мають психічні розлади (психічні вади здоров'я);

10) представники кримінального середовища, національних об'єднань кримінальної субкультури;

11) які намагаються допомогти уникнути відповідальності за адміністративні чи кримінальні правопорушення своїм родичам, друзям, знайомим;

12) які займають високе соціальне становище та/або матеріально забезпечені на високому рівні, негативно (зневажливо, зверхньо) ставляться до працівників правоохоронних органів

\footnotetext{
${ }^{1}$ Вознюк, А. А., Дудоров, О. О., Чернявський, С. С. (2021). Кримінальна відповідальність за злочини, вчинені злочинною спільнотою (статті 255, 255 $, 255^{2}, 255^{3}, 256$ Кримінального кодексу Украӥни): науково-практичний коментар. Київ: Норма права, 5-8; Вознюк, А. А. (2018). Теоретичні та практичні проблеми кримінальної відповідальності за створення злочинних об'єднань та участь у них як посягання на громадську безпеку: автореферат дисертації на здобуття наукового ступеня доктора юридичних наук. Київ: НАВС, 3; Вознюк, А. А. (2019). Реальні причини топ-корупції в Україні та нереальні способи протидії ій. Реалізація державної антикорупиійної політики в міжнародному вимірі: матеріали IV Міжнародної науково-практичної конферениії (12 грудня 2019 р., м. Київ), 1, 44-47; Дудоров, О. О., Коломоєць, Т. О., Кушнір, С. М., Макаренков, О. Л. (2019). Загально-теоретичні, адміністративно- та кримінально-правові основи концептуалізації антикорупиійної реформи в Україні. Запоріжжя, 6.
} 
та заздалегідь знають, що використовуючи корупційні зв'язки та матеріальне становище, не будуть притягнені до адміністративної або кримінальної відповідальності, їхні діти;

13) працівники органів державної влади чи місцевого самоврядування, зокрема правоохоронних органів, їх представники, родичі;

14) члени організованих злочинних груп і злочинних організацій з метою відверення уваги від злочинної діяльності, яку документують, чи мають намір «покривати за грошову винагороду» працівники правоохоронних органів;

15) з активною соціальною позицією, радикально налаштовані («активісти», «провокатори», «блогери»);

16) які усвідомлюють, що відносно них проводяться відповідні заходи документування та не бажають бути викритими (наприклад, високопосадовець, який вчинив латентний злочин);

17) колишні працівники ОВС;

18) особи, які дивлячись на безкарність одних, повторюють ті ж самі дії;

19) учасники масових акцій;

20) особи без постійного місця проживання.

У більшості випадків такі риси, як наявність судимості на час вчинення злочину чи в минулому, стан алкогольного, рідше наркотичного сп'яніння, аморальний спосіб життя, негативне ставлення до правоохоронних органів трапляються в різних комбінаціях, а відтак, поєднуються в різних типах суб'єктів злочинів, передбачених ст. 345 КК Украӥни.

Осіб, які вчиняють погрози або насильство щодо працівників правоохоронних органів, можна класифікувати за рівнем освіти, статтю, громадянством, віком, судимістю, способом вчинення відповідних суспільно небезпечних діянь тощо.

Зарубіжні вчені, які досліджували схожі та аналогічні кримінальні правопорушення, акцентують увагу на таких типах злочинців: нестійкий (допускаючий), ситуативний (не готується), небезпечний $\quad$ (плануючий $\quad$ (Д. С. Дроздов) ${ }^{1}$; криміногенний агресивно-насильницький, протестуючий, змішаний - ситуативно-агресивний (I. М. Шитяков) ${ }^{2}$; залежно від характеру та мотивації- корисливий, престижний, мстивий та залежно від ступеня стійкості кримінальної установки - професійний, випадковий, ситуативний (Р. Т. Гамідов) $)^{3} ;$ за ступенем стійкості кримінальної установки - злісний і ситуативний, залежно від характеру і мотивації вчинення злочину - корисливий, грайливий, мстивий (А. М. Гамідов) ${ }^{4}$; за характером злочинної спрямованості і ступенем деформації особистості- «послідовно-кримінальний», «ситуативно-кримінальний», «дезадаптивно-кримінальний», «вимушено-кримінальний» (М. Б. Моховий) ${ }^{5}$; інструментальний, ситуативний, мстивий (С. В. Пахомов)

В основі типології осіб, які вчиняють злочини, передбачені ст. 345 КК України, з огляду на результати вивчення судової практики та наукових досліджень, можуть бути покладені такі критерії як стійкість антисоціальної спрямованості правопорушника, його взаємовідносини з потерпілим,

\footnotetext{
${ }^{1}$ Дроздов, Д. Е. (2020). Криминологическая оценка и предупреждение применения насилия в отношении должностного лица правоохранительного органа: автореферат диссертации на соискание научной степени кандидата юридических наук. Москва: Московский университет Министерства внутренних дел Российской Федерации имени В.Я. Кикотя, 12.

2 Шитяков, И. Н. (2011). Обеспечение виктимологической безопасности сотрудников уголовно-исполнительной системы от криминальных посягательств осужденных: автореферат диссертации на соискание научной степени кандидата юридических наук. Рязань: Академия права и управления, 10.

${ }^{3}$ Гамидов, Р. Т. (2010). Применение насилия в отношении представителя власти: уголовно-правовое и криминологическое исследование (на примере Республики Дагестан): автореферат диссертации на соискание научной степени кандидата юридических наук. Москва: Российский университет дружбы народов, 19-20.

${ }^{4}$ Гамидов, А.М. (2006). Уголовно-правовые и криминологические аспекты посягательства на жизнь сотрудника правоохранительного органа: по материалам Республики Дагестан: диссертация на соискание научной степени кандидата юридических наук. Махачкала: ДГУ, 184-185.

${ }^{5}$ Моховой, М. Б. (2004). Криминологическая характеристика и предупреждение преступлений, посягающих на представителей власти: автореферат диссертации на соискание научной степени кандидата юридических наук. Краснодар: Краснодарская Академия МВД, 19-20.

${ }^{6}$ Пахомов, С. В. (2003). Проблемы методики расследования посягательства на жизнь сотрудника правоохранительного органа: диссертация на соискание научной степени кандидата юридических наук. Краснодар: Краснодарский юридический институт, 52-53.
} 
мотиви, мета, вид (спосіб) суспільно небезпечного діяння, досвід вчинення інших кримінальних правопорушень, стан сп'яніння на час вчинення кримінально протиправного діяння, вид правопорушення, яке передує погрозам або насильству щодо працівника правоохоронного органу, а також кількість суб' єктів злочину та форму співучасті.

I. Залежно від ступеня стійкості антисоціальної спрямованості можна виокремити такі типи злочинців:

1. Ситуативних (нестійких), які вчинили цей злочин з огляду на несприятливу для них ситуацію, пов'язану з вчиненням ними адміністративних правопорушень та відповідної реакції правоохоронців. Такі особи характеризуються, здебільшого, якщо не позитивно, то принаймні задовільно за місцем роботи, проживання чи навчання. Деформація їх морально-ціннісних орієнтирів $\epsilon$ незначною. Зазвичай, вони вчиняють погрози або завдають побоїв чи легких тілесних ушкоджень правоохоронцям, перебуваючи в стані сп'яніння.

Має рацію В.С. Ткаченко, що серед засуджених за посягання на правоохоронців переважають злочинці з ситуативною установкою. Зазначені особи, потрапляючи в конфліктну ситуацію, як правило, прагнули вирішити їі насильницькими засобами. Це підтверджується зокрема тим, що 42\% цих осіб характеризується як агресивні, 57\% були схильні до правопорушень, половина відбувала покарання за злочини, пов'язані із застосуванням насильства, 86\% 3 них зловживали спиртними напоями ${ }^{1}$.

Заслуговує на увагу і позиція М. Б. Мохового, відповідно до якої «ситуативно-кримінальний тип особи, яка посягає на представника влади» (62\%) характеризується агресивно-конфліктною поведінкою, яка $є$ наслідком неадекватного сприйняття законних дій потерпілих. Для них властива суттєва переоцінка мотиву порушення кримінального закону i, як наслідок, цього - впевненість у безкарності. Спонукальними мотивами осіб, які посягають, головним чином, виступає небажання бути затриманим, прагнення допомогти кому-небудь уникнути затримання або звільнити затриманих учасників, нейтралізувати співробітника, що створює протидію для правопорушника, інше перешкоджання законним вимогам представників влади на грунті виконання ними покладених на них обов'язків ${ }^{2}$.

Різновидом ситуативних злочинів цієї категорії слід визнати вимущений тип, до якого відносять особи, які вчинили злочин, передбачений ст. 345 КК України, через неправомірні дії правоохоронців. Посягання на цих представників влади може бути для них формою самозахисту або захисту близьких осіб. Вивчення судової практики свідчить про те, що окремі працівники поліції перевищують владу шляхом приниження правопорушників або застосування до них насильства. Наприклад, поліщейський сектору реагування патрульної полічії у приміщенні відділення полічії наніс один удар гумовим кийком по правій нозі особі, яка вчинила адміністративне правопорушення та перебувала в кімнаті затриманих, чим спричинив їй біль $i$ страждання. В подальшому полічейський, погрожуючи подальшим заподіянням тілесних ушкоджень, примусив потерпілого присідати, чим принизив та образив його особисту гідність ${ }^{3}$. 3 огляду на це не дивно, що окремі правоохоронці стають потерпілими від погроз або насильства з боку осіб, по відношенню до яких вони, як представники влади, застосували фізичне насильство або принизили їхню честь і гідність.

2. Злісних (стійких), які мають яскраво виражену кримінально протиправну спрямованість, раніше вчиняли злочини. Такі особи характеризуються за місцем роботи чи проживання негативно, рідше - задовільно. Деформація їх морально-ціннісних орієнтирів $є$ значною. Вони воліють конфліктні ситуації вирішувати шляхом застосування насильства та ненавидять працівників правоохоронних органів. Можуть вчиняти як погрози, так і завдавати тілесних ушкоджень будьякого ступеня тяжкості.

\footnotetext{
${ }^{1}$ Ткаченко, В.С. (1998). Уголовно-правовая охрана личности сотрудников правоохранительных органов, обеспечивающих общественный порядок и общественную безопасность: диссертаиия на соискание научной степени кандидата юридических наук. Москва: Академия Управления МВД РФ, 165.

${ }^{2}$ Моховой, М. Б. (2004). Криминологическая характеристика и предупреждение преступлений, посягающих на представителей власти: автореферат диссертачии на соискание научной степени кандидата юридических наук. Краснодар: Краснодарская Академия МВД, 19-20.

${ }^{3}$ Вирок № 1-кn/153/25/20-к, 2020 (Ямпільський районний суд Вінницької області). Єдиний державний реєстр судових рімень <https://reyestr.court.gov.ua/Review/89022141> (2021, серпень, 20).
} 
3. Особливо небезпечних, які характеризуються особливою небезпекою з огляду на те, що є здебільшого представниками організованої кримінально протиправної діяльності, зокрема керівниками та активними учасниками організованих злочинних об'єднань, кримінальними авторитетами. Можуть мати декілька судимостей, насамперед, за насильницькі злочини. Це професійні злочинці. Свої посягання щодо працівників правоохоронних органів можуть планувати заздалегідь.

II. Залежно від взаємовідносин з потерпілим кримінальних правопорушників досліджуваної категорії варто класифікувати на:

1) осіб, які були раніше знайомі з потерпілим. Такі кримінальні правопорушники трапляються рідко. Як правило, вони діють з мотивів помсти або невдоволення попередніми діями правоохоронців;

2) осіб, які не були раніше знайомі з потерпілим. Такі особи складають найбільшу частку кримінальних правопорушників цієї категорії.

III. Вивчення мотивів погроз або насильства щодо працівників правоохоронних органів дозволяє виділити такі типи кримінальних правопорушників досліджуваної категорії:

1) корисні, які вчиняють цей злочин з метою уникнення затримання, притягнення до адміністративної чи кримінальної відповідальності;

2) престижні, які прагнуть шляхом своїх кримінально протиправних дій, утвердити чи збільшити свій авторитет серед оточуючих. Це так звані «блогери» та «активісти». Шляхом посягань на правоохоронців вони бажають проявити себе;

3) мстиві, які мають ненависть до правоохоронців за їх правомірні чи протиправні дії i бажають помститися працівникам правоохоронних органів шляхом погроз чи насильства.

IV. За наявністю чи відсутністю досвіду вчинення інших кримінальних правопорушень на час вчинення погрози або насильства щодо працівника правоохоронного органу трапляються:

1) особи, які раніше не вчиняли кримінальних правопорушень;

2) підозрювані, обвинувачені у вчиненні кримінальних правопорушень;

3) судимі;

4) раніше судимі (мають зняту чи погашену судимість).

Особи, що мають судимість та раніше судимі за тяжкі та особливо тяжкі насильницькі злочини є найбільш небезпечними злочинцями цієї категорії.

Цікавим $є$ той факт, що особи, які мають попередній досвід кримінально протиправної діяльності вчиняють погрози або насильство щодо правоохоронців, перебуваючи не на волі, а, наприклад, у місцях попереднього ув'язнення ${ }^{1}$ чи відбування покарання ${ }^{2}$. Що може свідчити як про вперте їх небажання ставати на шлях виправлення, так і про відсутність страху перед кримінальною відповідальністю (адже їх особу встановлено, а самі вони перебувають у місцях позбавлення волі) або ж неправомірні дії правоохоронців, які спровокували кримінальних правопорушників на вчинення злочину, передбаченого ст. 345 КК України.

V. За видом (способом) протиправних дій серед осіб які вчиняють злочини, передбачені ст. 345 КК України, варто виокремити:

1) осіб, які вчиняють погрози вбивством, насильством або знищенням чи пошкодженням майна щодо працівника правоохоронного органу, а також щодо його близьких родичів у зв'язку з виконанням цим працівником службових обов'язків;

2) осіб, які вчиняють умисне заподіяння працівникові правоохоронного органу чи його близьким родичам побоїв або легких тілесних ушкоджень у зв'язку з виконанням цим працівником службових обов'язків;

3) осіб, які вчиняють умисне заподіяння працівникові правоохоронного органу чи його близьким родичам середньої тяжкості тілесних ушкоджень у зв'язку з виконанням цим працівником службових обов'язків;

4) осіб, які вчиняють умисне заподіяння працівникові правоохоронного органу чи його близьким родичам тяжкого тілесного ушкодження у зв'язку з виконанням цим працівником службових обов'язків.

\footnotetext{
${ }^{1}$ Постанова № 761/29362/15-к, 2018 (Касаційний кримінальний суд Верховного Суду України). Сдиний державний реєстр судових рімень <https://reyestr.court.gov.ua/Review/76103374> (2021, серпень, 20).

${ }^{2}$ Постанова № 648/1983/15-к, 2018 (Касаційний кримінальний суд Верховного Суду України). Сдиний державний реєстр судових рімень <https://reyestr.court.gov.ua/Review/75498379> (2021, серпень, 20).
} 
VI. Окремі опитувані правоохоронці диференціюють категорії кримінальних порушників залежно від виду суспільно небезпечного діяння, зокрема зазначають, що погрози вчиняються найчастіше особами, підозрюваними у вчиненні кримінальних правопорушень або їх родичами чи знайомими. Насильницькі дії найчастіше вчиняють особи, затримані за вчинення адміністративного правопорушення і перебувають на час затримання в стані алкогольного або наркотичного сп'яніння.

VII. За наявністю чи відсутністю стану сn'яніння на час вчинення погрози або насильства щодо працівника правоохоронного органу:

1) особи, які під час злочину, перебували в стані сп'яніння;

2) особи, які під час злочину, не перебували в стані сп'яніння.

VIII. За метою погрози або насильства щодо працівника правоохоронного органу трапляються:

1) особи, які вчиняють злочин з метою ухилення від адміністративного чи кримінального правопорушення. Це особи, яких фактично викрито після вчинення правопорушення (наприклад, працівник лісового господарства зупинив лісовоз, прикордонник затримав контрабандиста на гарячому, працівник поліції зупинив транспортний засіб з явними ознаками знищення чи зміни номерів вузлів та агрегатів автомобіля), однак вони жадають уникнути юридичної відповідальності, а тому вчиняють погрози або насильство щодо працівників правоохоронних органів. Посягання на правоохоронців за таких обставин вчиняється до моменту прийняття рішення щодо винуватості та накладення стягнення, або до застосування заходів примусу тощо;

2) особи, які вчиняють злочин з метою помсти за правомірні дії працівника правоохоронного органу (наприклад, помсти слідчому, який розслідував вчинене кримінальне правопорушення);

3) особи, які вчиняють злочин з метою помсти за неправомірні дії працівника правоохоронного органу (наприклад, помсти працівнику оперативного підрозділу, який виявив кримінальне правопорушення або брав участь у затриманні особи, яка вчинила злочин).

IX. За видом правопорушення, яке передує погрозам або насильству щодо працівника правоохоронного органу у судовій практиці найчастіше трапляються такі категорії кримінальних правопорушників:

1) водії транспортних засобів, які порушили правила дорожнього руху та їх пасажири;

2) особи, які вчинили хуліганство або дрібне хуліганства;

3) особи, які розпивають пиво, алкогольні, слабоалкогольні напої у заборонених законом місцях або з'являються у громадських місцях у п'яному вигляді;

4) особи, які вчинили домашнє насильство.

IX. У певних випадках ці злочини вчиняють у співучасті, однак здебільшого вони залишаються латентними для офіційної статистики. 3 огляду на це, залежно від кількості осіб, які погрожують правоохоронцям чи вчиняють насильство щодо них, наявності домовленостей між ними та часу іiі досягнення, розподілу функцій, наявності стійкості та інших кримінально-правових ознак певної форми співучасті суб'єктів злочину, передбаченого ст. 345 КК України, можна класифікувати на:

1) осіб, які діють одноособово (така ситуація має місце у переважній більшості випадків);

2) осіб, які діють у складі групи без попередньої змови (наприклад, це можуть бути очевидці резонансної ДТП, які невдоволені діями поліцейського на місці події або дружина у випадку затримання ії чоловіка чи застосовування до нього заходів примусу);

3) осіб, які діють у складі групи за попередньою змовою (наприклад, це можуть бути активісти, які заздалегідь домовилися напасти на поліцейських з метою уникнення відповідальності певною особою);

4) осіб, які діють у складі організованого злочинного об'єднання - організованої групи, злочинної організації, банди (наприклад, це можуть бути члени банди, які намагаються уникнути затримання).

Висновки. Таким чином, осіб, які вчиняють погрози або насильство щодо правоохоронців можна класифікувати залежно від ступеня стійкості антисоціальної спрямованості (ситуативний (нестійкий), вимушений, злісний (стійкий), особливо небезпечний типи); взаємовідносин з потерпілим (раніше знайомі з потерпілим та раніше не знайомі з потерпілим); мотивів (корисний, престижний, мстивий типи); досвіду вчинення інших кримінальних правопорушень (особи, які раніше не вчиняли кримінальних правопорушень; підозрювані, обвинувачені у вчиненні кримінальних правопорушень; судимі, раніше судимі); видом (способом) протиправних дій (осіб, 
які вчиняють погрози вбивством, насильством або знищенням чи пошкодженням майна; осіб, які вчиняють умисне заподіяння побоїв або легких тілесних ушкоджень; осіб, які вчиняють умисне заподіяння середньої тяжкості тілесних ушкоджень; осіб, які вчиняють умисне заподіяння тяжкого тілесного ушкодження); виду суспільно небезпечного діяння (особи, які вчиняють погрози; особи, які застосовують фізичне насильство); стану сп'яніння (особи, які під час злочину, перебували в стані сп'яніння; особи, які під час злочину, не перебували в стані сп'яніння); метою (особи, які вчиняють злочин з метою ухилення від адміністративного чи кримінального правопорушення; особи, які вчиняють злочин з метою помсти за правомірні дії працівника правоохоронного органу; особи, які вчиняють злочин з метою помсти за неправомірні дії працівника правоохоронного органу); видом правопорушення, яке передує погрозам або насильству щодо працівника правоохоронного органу (водії транспортних засобів, які порушили правила дорожнього руху та їхні пасажири; особи, які вчинили хуліганство або дрібне хуліганство; особи, які розпивають пиво, алкогольні, слабоалкогольні напої у заборонених законом місцях або з'являються у громадських місцях у стані сп'яніння; особи, які вчинили домашне насильство); кількістю суб'єктів злочину та різновидом форми співучасті (осіб, які діють одноособово; осіб, які діють у складі групи без попередньої змови; осіб, які діють у складі групи за попередньою змовою; осіб, які діють у складі організованого злочинного об'єднання).

Зазначені та інші критерії класифікації, а також виокремлені на їх основі типи правопорушників цієї категорії, дозволяють диференційовано та комплексно підійти до формування тактики та стратегії протидії погрозам або насильству щодо правоохоронців, насамперед поліцейських, та сформувати систему адекватних заходів запобігання цим суспільно небезпечним діянням.

\section{References:}

1. Vozniuk, A. A., Dudorov, O.O., Cherniavskyi, S.S. (2021). Kryminalna vidpovidalnist za zlochyny, vchyneni zlochynnoiu spilnotoiu (statti $255,255^{1}, 255^{2}, 255^{3}, 256$ Kryminalnoho kodeksu Ukrainy): naukovo-praktychnyi komentar [Criminal liability for crimes committed by the criminal community (Articles 255, 255 $, 255^{2}, 255^{3}, 256$ of the Criminal Code of Ukraine): scientific and practical commentary]. Kyiv: Norma prava. [in Ukrainian].

2. Vyrok № 1-kp/153/25/20-k, 2020 (Yampilskyy rayonnyy sud Vinnytskoyi oblasti) [Sentence № 1-kp / 153/25/20-k, 2020 (Yampil District Court of Vinnytsia Region)]. Yedynyy derzhavnyy reyestr sudovykh rishen [Unified state register of court decisions] <https://reyestr.court.gov.ua/Review/89022141> (2021, August, 20). [in Ukrainian].

3. Voznyuk, A. A. (2018). Teoretychni ta praktychni problemy kryminalnoyi vidpovidalnosti za stvorennya zlochynnykh obyednan ta uchast u nykh yak posyahannya na hromadsku bezpeku [Theoretical and practical problems of criminal liability for the creation of criminal associations and participation in them as an encroachment on public safety]: avtoreferat dysertatsiyi na zdobuttya naukovoho stupenya doktora yurydychnykh nauk [the abstract of the dissertation for the degree of Doctor of Laws]. Kyiv: NAVS. [in Ukrainian].

4. Voznyuk, A. A. (2019). Realni prychyny top-koruptsiyi v Ukrayini ta nerealni sposoby protydiyi yiy [Real causes of top corruption in Ukraine and unrealistic ways to counter it]. Realizatsiya derzhavnoyi antykoruptsiynoyi polityky v mizhnarodnomu vymiri: materialy IV Mizhnarodnoyi naukovo-praktychnoyi konferentsiyi (12 hrudnya 2019 r., $m$. Kyiv) [Implementation of the state anti-corruption policy in the international dimension: materials of the IV International scientific-practical conference (December 12, 2019, Kyiv], 1, 44-47. [in Ukrainian].

5. Gamidov, R.T. (2010). Primeneniye nasiliya v otnoshenii predstavitelya vlasti: ugolovno-pravovoye i kriminologicheskoye issledovaniye (na primere Respubliki Dagestan) [The use of violence against a government official: criminal law and criminological research (on the example of the Republic of Dagestan)]: avtoreferat dissertatsii na soiskaniye nauchnoy stepeni kandidata yuridicheskikh nauk [thesis abstract for the degree of candidate of legal sciences]. Moscow: Peoples' Friendship University of Russia. [in Russian].

6. Gamidov, A. M. (2006). Ugolovno-pravovyye i kriminologicheskiye aspekty posyagatelstva na zhizn sotrudnika pravookhranitelnogo organa: po materialam Respubliki Dagestan [Criminal-legal and criminological aspects of encroachment on the life of a law enforcement officer: based on the materials of the Republic of Dagestan]: dissertatsiya na soiskaniye nauchnoy stepeni kandidata yuridicheskikh nauk [dissertation for the degree of candidate of legal sciences]. Makhachkala: DGU. [in Russian].

7. Drozdov, D.E. (2020). Kriminologicheskaya otsenka i preduprezhdeniye primeneniya nasiliya v otnoshenii dolzhnostnogo litsa pravookhranitelnogo organa [Criminological Assessment and Prevention of the Use of Violence Against an Official of a Law Enforcement Agency]: avtoreferat dissertatsii na soiskaniye nauchnoy stepeni kandidata yuridicheskikh nauk [thesis abstract for the degree of candidate of legal sciences]. Moscow: Moscow University of the Ministry of Internal Affairs. [in Russian].

8. Dudorov, O. O., Kolomoyets, T. O., Kushnir, S. M., Makarenkov, O. L. (2019). Zahalno-teoretychni, administratyvno- ta kryminalno-pravovi osnovy kontseptualizatsiyi antykoruptsiynoyi reformy v Ukrayini 
[General-theoretical, administrative- and criminal-legal bases of conceptualization of anti-corruption reform in Ukraine]. Zaporizhzhia. [in Ukrainian].

9. Mokhovoy, M. B. (2004). Kriminologicheskaya kharakteristika i preduprezhdeniye prestupleniy, posyagayushchikh na predstaviteley vlasti [Criminological characteristics and prevention of crimes encroaching on representatives of the authorities]: avtoreferat dissertatsii na soiskaniye nauchnoy stepeni kandidata yuridicheskikh nauk [the author's abstract of the thesis for the scientific degree of candidate of legal sciences]. Krasnodar: Krasnodar Academy of the Ministry of Internal Affairs. [in Russian].

10. Pakhomov, S.V. (2003). Problemy metodiki rassledovaniya posyagatelstva na zhizn sotrudnika pravookhranitelnogo organa: [Problems of the methodology of investigating the encroachment on the life of a law enforcement officer]: dissertatsiya na soiskaniye nauchnoy stepeni kandidata yuridicheskikh nauk [dissertation for the degree of candidate of legal sciences]. Krasnodar: Krasnodar Law Institute. [in Russian].

11. Postanova № 648/1983/15-k, 2018 (Kasatsiynyy kryminalnyy sud Verkhovnoho Sudu Ukrayiny) [Resolution № 648/1983/15-k, 2018 (Criminal Court of Cassation of the Supreme Court of Ukraine)]. Yedynyy derzhavnyy reyestr sudovykh rishen [Unified state register of court decisions]<https://reyestr.court.gov.ua/Review/75498379> (2021, August, 20). [in Ukrainian].

12. Postanova № 761/29362/15-k, 2018 (Kasatsiynyy kryminalnyy sud Verkhovnoho Sudu Ukrayiny) [Resolution № 761/29362/15-k, 2018 (Criminal Court of Cassation of the Supreme Court of Ukraine)]. Yedynyy derzhavnyy reyestr sudovykh rishen [Unified state register of court decisions]<https://reyestr.court.gov.ua/Review/76103374> (2021, August, 20). [in Ukrainian].

13. Tkachenko, V. S. (1998). Ugolovno-pravovaya okhrana lichnosti sotrudnikov pravookhranitelnykh organov, obespechivayushchikh obshchestvennyy poryadok i obshchestvennuyu bezopasnost[Criminal legal protection of the identity of law enforcement officers ensuring public order and public safety]: dissertatsiya na soiskaniye nauchnoy stepeni kandidata yuridicheskikh nauk [dissertation for the degree of candidate of legal sciences]. Moscow: Academy of Management of the Ministry of Internal Affairs of the Russian Federation. [in Ukrainian].

14. Shityakov, I. N. (2011). Obespecheniye viktimologicheskoy bezopasnosti sotrudnikov ugolovno-ispolnitel'noy sistemy ot kriminal'nykh posyagatel'stv osuzhdennykh [Ensuring the victimological safety of employees of the penal system from criminal encroachments by convicts]: avtoreferat dissertatsii na soiskaniye nauchnoy stepeni kandidata yuridicheskikh nauk [thesis abstract for the degree of candidate of legal sciences]. Ryazan: Academy of Law and Management. [in Ukrainian]. 